\title{
Concrete modulus of elasticity assessment using digital image correlation
}

\section{Determinação do módulo de elasticidade do concreto utilizando a correlação de imagem digital}

\author{
A. H. A. SANTOS a \\ ayrtonhugo@yahoo.com.br \\ R. L. S. PITANGUEIRA a \\ roque@dees.ufmg.br \\ G. O. RIBEIRO \\ gabriel@dees.ufmg.br \\ E. V. M. CARRASCO a \\ mantilla@dees.ufmg.br
}

\begin{abstract}
This paper presents the use of the technique of digital image correlation for obtaining the elasticity modulus of concrete. The proposed system uses a USB microscope that captures images at a rate of five frames per second. The stored data are correlated with the applied loads, and a stress-strain curve is generated to determine the concrete compressive modulus of elasticity. Two different concretes were produced and tested using the proposed system. The results were compared with the results obtained using a traditional strain gauge. It was observed a difference in the range of $4 \%$ between the two methods, wherein this difference depends on some parameters in the case of the DIC results, as focal length and a video capture resolution, indicating that DIC technique can be used to obtain mechanical properties of concrete.
\end{abstract}

Keywords: experimental testing, concrete strain, concrete structures.

\section{Resumo}

O presente artigo apresenta o uso da técnica de correlação de imagem digital para a obtenção do módulo de elasticidade do concreto. O sistema proposto utiliza um microscópio USB que capta as imagens a uma taxa de 5 quadros por segundo. Posteriormente, os dados armazenados são compatibilizados com as cargas aplicadas e a curva tensão-deformação é gerada para determinação do módulo de elasticidade longitudinal do concreto à compressão. Dois concretos distintos foram produzidos e ensaiados utilizando o sistema proposto. Os resultados foram comparados com os obtidos com a metodologia tradicional, que utiliza Clips Gauges. Foi observada uma diferença na faixa de $4 \%$ entre os dois métodos, sendo que essa diferença depende de alguns parâmetros no caso dos resultados do DIC, a distância focal e a resolução do vídeo, indicando que a técnica de correlação de imagem digital pode ser utilizada para a obtenção de propriedades mecânicas do concreto.

Palavras-chave: análise experimental, deformação do concreto, estruturas de concreto.

Department of Structural Engineering, School of Engineering of the Federal University of Minas Gerais, Belo Horizonte, MG, Brazil. 


\section{Introduction}

An evaluation of the concrete compressive modulus of elasticity is obtained directly from the stress-strain curve experimentally. Normal techniques, such as the Brazilian standard (NBR 8522 [1]) and the American standard (C469 [2]), suggest methods for concrete strain determination using an electrical resistance strain gauge, a demec mechanical strain gauge and a compressometer. An electrical strain gauge is the most widely used method for concrete strain determination (HUANG[3]). However, the adhesion of the strain gauge in a concrete sample requires time and attention from the workers, and the adhesion is not reused and results in a technique that is unsustainable. Additionally, the use of a strain gauge determines the size of the concrete samples for this application. Consequently, a strain gauge cannot be attached to smaller or larger parts unless the size is specified by the strain gauge producers. In recent decades, new technologies, such as acoustic emission (HUANG et al. [4] and KORENSKA et a.I.[5]), digital image correlation (CHU et al. [6],SUTTON et al.[7], BRUCK et al.[8], LUO et al. [9], HUANG et al. [10], SANTOS et al.[11]) and shearography (HUNG [12], HUANG et al.[13]), have been used for certain mechanical parameters of concrete, including the elasticity modulus. Among these techniques, digital image correlation (DIC) has gained rapid recognition. The DIC technique has several advantages, including accuracy, dynamics and the rapid analysis of data. This technique uses speckle patterns (natural or artificial) as information carriers. By matching the surface speckles captured be- fore and after a deformation or displacement using a correlation function, adequate speckle displacement can be easily obtained (SUTTON et al.[14]).

The use of the DIC technique has been widely accepted in structures engineering because it is an important method for characterizing the mechanical response of homogenous (LAGATTU et al. [15], LOCKWOOD et al. [16], REYNOLDS and REYNOLDS[17], YAN and SUTTON[18]) and heterogeneous materials (PETERS and RANSON[19], CHOI and SHAH [20], PAN et al. [21], MCCORMICK and LORD [22], SUTTON et al.[23] undergoing nominally planar deformation, especially when evaluating the fracture behavior (CORR et al. [24], HELM [25], SUBRAMANIAN et al.[26], WU et al. [27]. When using the DIC technique for an evaluation of the elasticity modulus of concrete, the work of ROBERT et al. [28] was the first to demonstrate excellent correlation between the results obtained for the DIC technique with the results obtained by the traditional method. Other work which also made this comparison was to HUANG et al.[3]. In this study, HUANG et al.[3] used two high-resolution CCD cameras equipped with long working distance lens. The proposed system that is presented in this paper uses a single USB microscope.

Using the principle of DIC, the motion estimated for each point is obtained from the expansion of the imaging system (correlation in $\mathrm{mm} /$ pixel). According to PAN et al.[21] and SUTTON et al. [29], this estimate only depicts the real point of movement if two requirements are met: (a) the sample surface must be at an angle of 90 degrees to the sensor pickup and remain in this position during loading; (b) the image should not suffer from geometric distortion. Figure 1 shows images of a random pattern of a surface captured
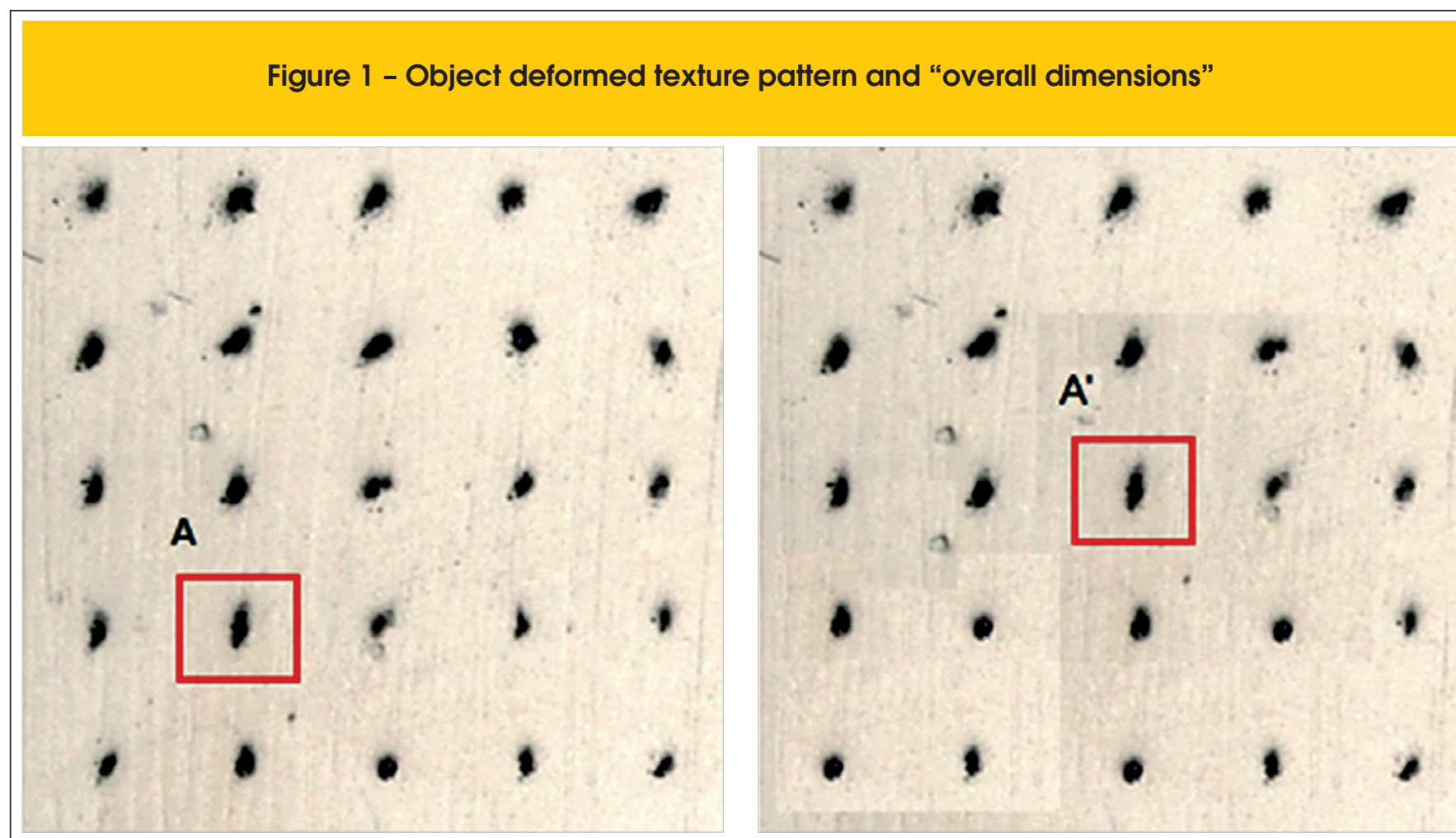

A Reference image

B Deformed image 


\section{Figure 2 - System that captures digital images}

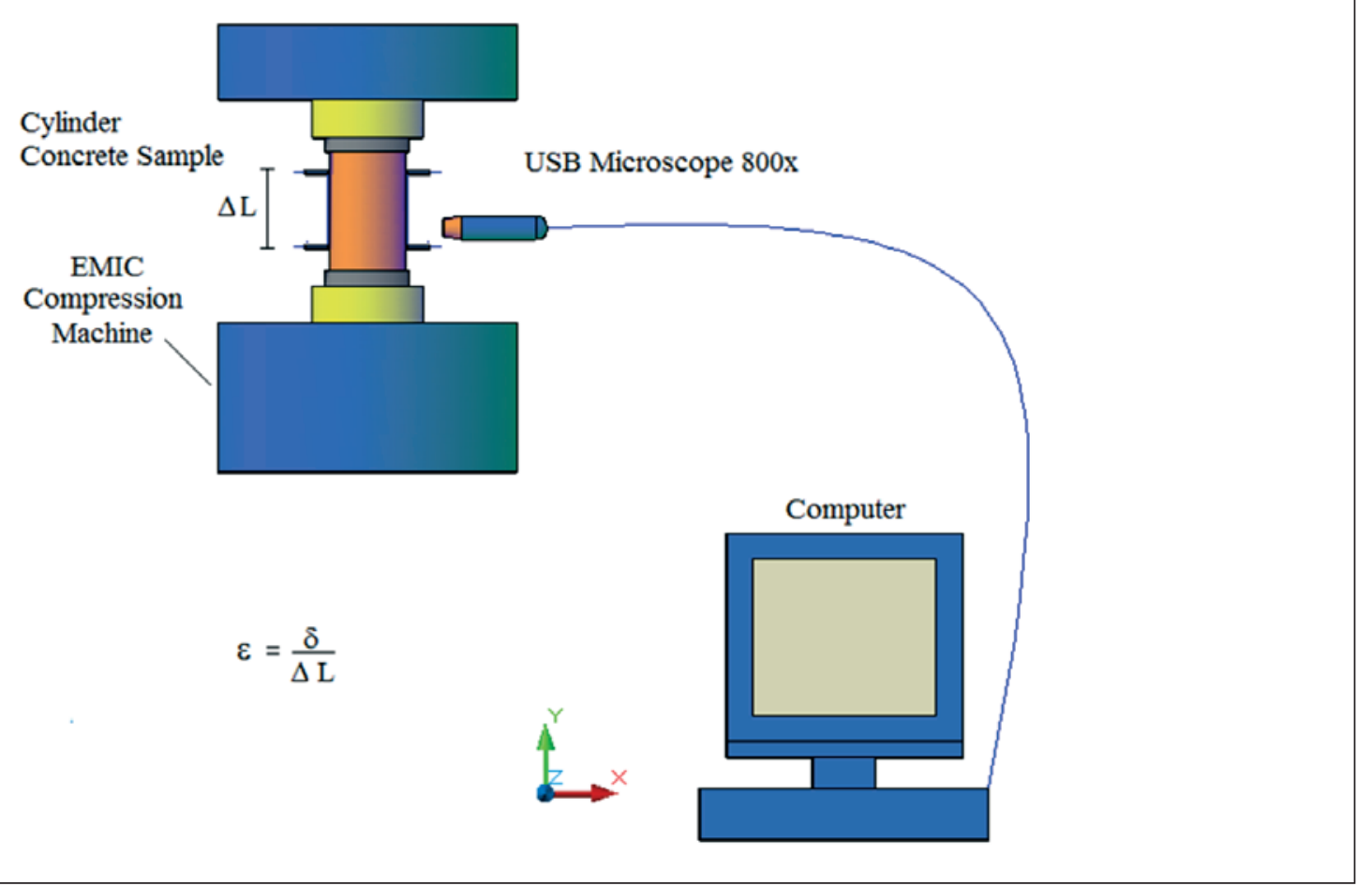

before and after deformation. To determine the displacement of point $A$, a region near this point is chosen in the reference image (Figure 1a) and in the combined deformed image (Figure 1b). The centroid of the selected rectangular area is used as a reference point for measuring the relative displacements. Additionally, the vertices of the rectangle are used by the image processing software to check the rotation and/or translation of the point.

After capturing the images and the definition of the reference points, subroutines are processed using specific software to store the displacements as rotations (image by image) or as generating coordinates $(\mathrm{x}, \mathrm{y})$ (point by point), which are converted using the ratio of pixels per unit length and are adopted as "overall dimensions" as shown in Figure. 1.

This article aims to evaluate the DIC technique for obtaining the elasticity modulus of concrete. Next, specimens of concrete, which were prepared for two different compositions, were used for the test of uniform axial compression. The DIC technique results were compared with the results obtained using the strain gauge methods.

The DIC technique was applied using the USB microscope (800x) and specific software. The elasticity modulus of the concrete was determined using the stress-strain diagram.

\section{Material and methods}

According to Pan et al.[21], the DIC technique consists of three consecutive steps: (a) The preparation of the sample surface and the experiment, (b) The recording images from the planar surface of the sample before and after the application of the load, (c) The processing of images acquired using appropriate algorithms to obtain the desired displacements and deformations.

Figure 2 shows the schematic setup of the proposed system for monitoring the deformation of the concrete. A single high-resolution USB microscope was used to capture images in a region (2.0 $\mathrm{cm} \times 1.5 \mathrm{~cm})$. The USB digital microscope (800x) has an image sensor of 1.2 megapixels and a video capture resolution of 1280 $x 960$ pixels. The rate of capture of the images is five frames per second and is recorded in an AVI video format no compression. The lighting is generated by an LED lamps' microscope.

For the image processing was developed an software using the LabVIEW platform. This software was divided into four parts: 1) Digital Image Acquisition; 2) Data Input; 3) the image processing and 4) Results presentation. In the first stage, images of the specimen, which is already subjected to axial loading, are captured using the USB Microscope 800x. These images are stored in the software memory. In the second step, on first captured image is performed the marking of the area of interest to be studied, from points of interest (Figure 3). These points have a ratio pixel / mm that is transferred to the software memory. The area of interest's center of mass is the reference for the displacement measurements, while the vertices of the area of interest's rectangle are the references used by the processing routines to indicate whether there was rotation or not at the selected point on the surface of the specimen during the test. The point of interest's shape is stored in the software memory by contrast variation of pixels and its distance from the area of interest's center of mass. 


\section{Figure 3 - Determination of analysis points}
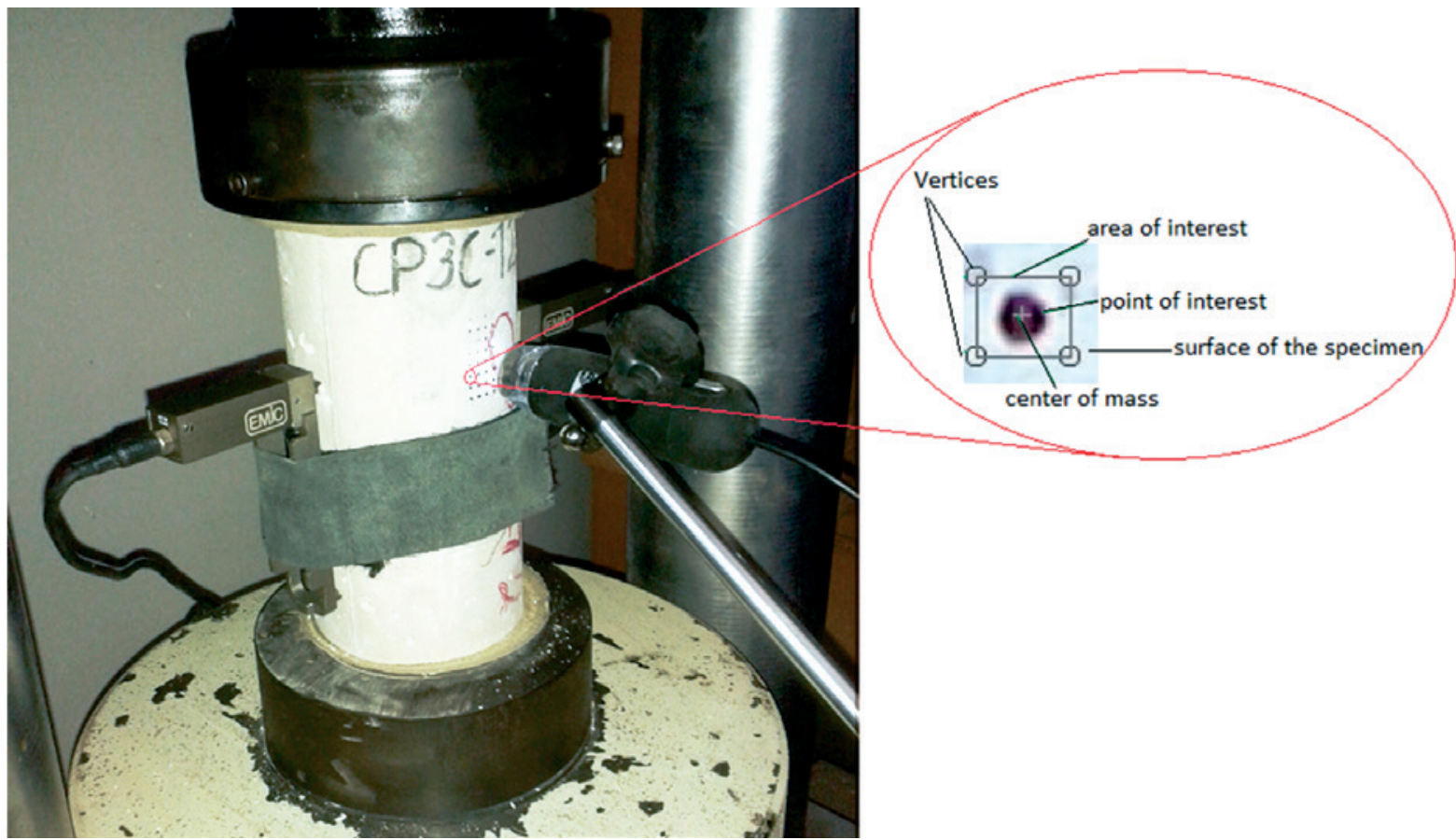

In the third step, the software calculates, frame to frame, the movements of translation and rotation of the points of interest. The determination of these points coordinates is performed using two specific routines implemented in the software for processing images, which are: shift invariant and rotation invariant. The first routine considers that occurs only small rotations of the area of inter- est during image processing and that these rotations are up to by four degrees. The second routine considers that will have rotations above four degrees of the area of interest. After the image processing matrices are generated with the coordinates $(x, y)$ to the area of interest's center of mass displacement in each processed image. These displacements are measured in pixels. The last part of the

Figure 4 - Grading curve for (a) fine aggregate, (b) coarse aggregate limestone

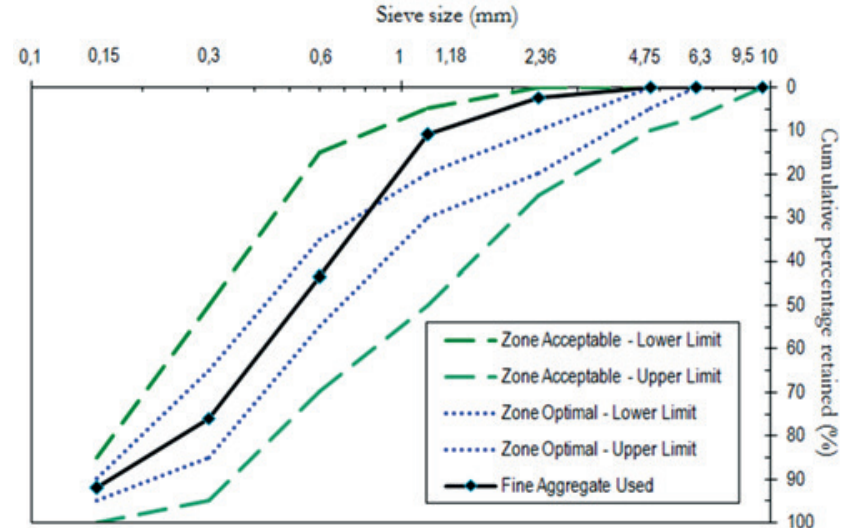

A

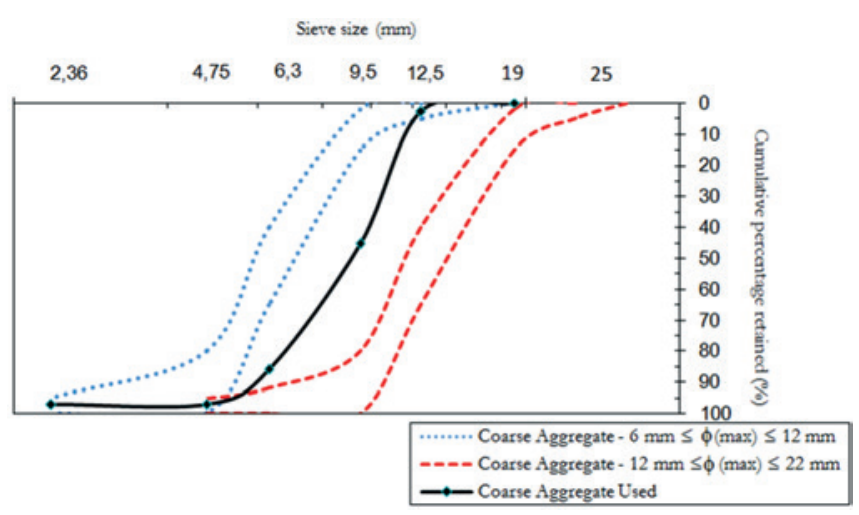

B 
Table 1 - Cement characteristics - CP V ARI RS

\begin{tabular}{|cccccccc} 
Concrete & $\begin{array}{c}\text { Cement } \\
\left(\mathrm{kg} / \mathrm{m}^{3}\right)\end{array}$ & $\begin{array}{c}\text { Coarse } \\
\text { aggregate } \\
\left(\mathrm{kg} / \mathrm{m}^{3}\right)\end{array}$ & $\begin{array}{c}\text { Fine aggregate } \\
\left(\mathrm{kg} / \mathrm{m}^{3}\right)\end{array}$ & $\begin{array}{c}\text { Water } \\
\left(\mathrm{kg} / \mathrm{m}^{3}\right)\end{array}$ & $\begin{array}{c}\text { Water/cement } \\
\text { ratio A/C }\end{array}$ & $\begin{array}{c}\mathrm{F}_{c} 28 \\
(\mathrm{MPa})\end{array}$ \\
\hline $\mathrm{L}_{1}$ & 400 & 1200 & 600 & 220 & 0,50 & 40 \\
$\mathrm{~L}_{2}$ & 400 & 1200 & 600 & 220 & 0,55 & 33 \\
\hline
\end{tabular}

software searches for these matrices and converts the distance from pixels to millimeters. Stress - strain curve are generated from these matrices and load cell data.

Ten standard cylindrical concrete samples that have a $100-\mathrm{mm}$ diameter and a 200-mm length were produced.

The specimen is under uniform axial compression, which is calculated using the ratio between the load and the initial cross-sectional area of the specimen (Figure 2). The longitudinal strain of the concrete cylinder is obtained from the relative displacement $(\delta)$ in the axial direction of two points, is used as the basis of measurement $\Delta \mathrm{L}$ ) and is located on the surface on the specimen surface in the cylinder generatrix. Using the stress-strain diagram, the elasticity modulus of the concrete is determined.

In this paper the surface of the specimen cylindrical is not at angle of 90 degree to the sensor as indicated by PAN et al. [21] and SUTTON et al.[29]. However, for calculation of the deformation using the DIC was used the average value between pairs of points within the monitored area, so that the distortion occurred can be disregarded.

The studied region was prepared prior to testing by sanding the surface and was sprayed with black and white speckles to provide a good contrast image. A template with points spaced at 0.5 $\mathrm{mm}$ is generated. The test can be performed without any surface preparation, but the assurance of the monitoring points will be dependent on the randomness of the medium. The focal length of the microscope was $5 \mathrm{~cm}$ with an optical zoom of 200 times (200x). Next, the obtained digital scale was approximately $2 \mu \mathrm{m} / \mathrm{pixel}$ in both image directions. This ratio is suitable for determining deformations that are uniform and constant, when the precision of the deformation attainable is from $153 \mu \varepsilon$.

The proposed method uses samples that were created with a concrete mixture. Both were produced by coarse aggregate limestone, river sand and cement (CP II - E32). No additives were included in the mixture. Figure 4 shows the grading curves of the coarse and fine aggregates, which have a maximum diameter $\left(\phi_{\max }\right)$ of $2.4 \mathrm{~mm}$ and $12.5 \mathrm{~mm}$, respectively.

The two types of concrete are denoted by $L_{1}$ and $L_{2}$. The mix proportions are listed in Table 1. The compressive strength test was performed, and the samples were healed outdoors for 28 days and were protected from direct sunlight.

The average compressive strength that was determined at 28 days ( $f_{c} 28$ ) was $40 \mathrm{MPa}$ (for $\mathrm{L}_{1}$ concrete) to $33 \mathrm{MPa}$ (for $\mathrm{L}_{2}$ concrete).

Following a standard concrete testing method indicated by technical standards [1,2], specimens were prepared with a surface flatness of contact using sulfur-based capping. The axial compression tests were performed using a servo-hydraulic machine EMIC, Model PC 200. When the cylinder sample was compressed, a series of images was captured and analyzed. To determine the elas- tic modulus, the elastic section of the stress-strain curve was considered in the narrow range between $0.5 \mathrm{MPa}$ and was $30 \%$ of the ultimate concrete strength. The data of the compressive strength were previously estimated using the uniaxial compression test, and the strength data were used to determine the ultimate loading for the cylinder specimens and to determine the static modulus of elasticity in compression. The value of $0.5 \mathrm{MPa}$ is used to ensure a uniform contact between the specimen and the machine, which leads to an approximate initial deformation of $0.0001 \mathrm{~mm} / \mathrm{mm}$

\section{Figure 5 - Real setup of the experiment using a servo-hydraulic machine EMIC, Model PC 200 and an USB microscope (800x). The sample is also affixed with traditional strain gauges (mechanical extensometer)}

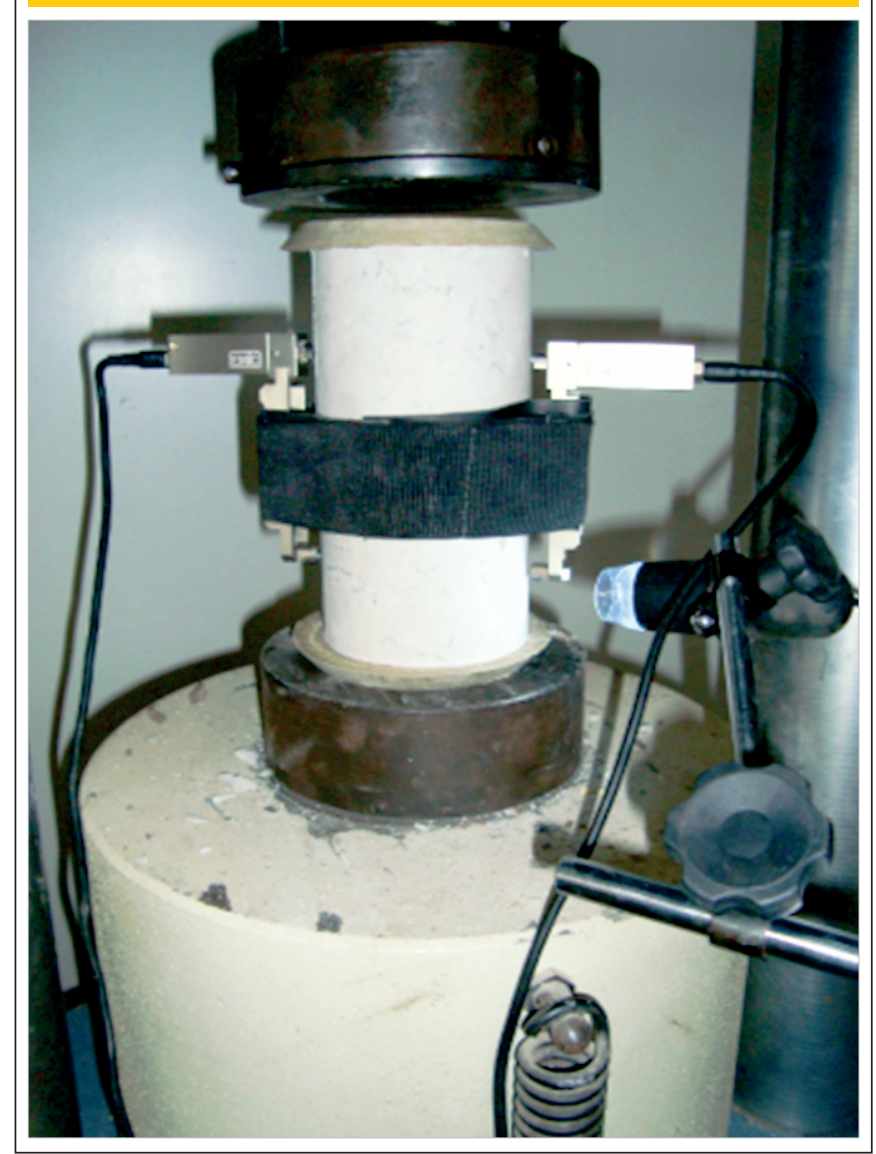


Loading and unloading cycles were performed to stabilize the test at a rate of $0.45 \mathrm{MPa} / \mathrm{s}$ for intervals of 30 seconds between loading and unloading.

Using the system of data capture called SPIDER 8, the displacements' information and the applied loads were stored in time. The images captured by the microscope were simultaneously stored on a hard disk in parallel. Once, the data capture system and the microscope are decoupled the variable "time" was adopted as the parameter compatibility information.

The compatibility was performed using an electronic spreadsheet, where, before performing the assay, the simultaneity of the system clocks data capture and the USB microscope was done. Additionally, an equivalent definition for the sampling frequency of the numerical data $(5 \mathrm{~Hz})$ and for the rate of image capture $(5 \mathrm{fps})$ was performed before the test. Figure 5 shows a photograph of the experiment assembly.

In addition to the USB microscope (800x), traditional strain gauges (Clip Gauges) were installed diametrically (i.e., opposite the surface of the specimen) to obtain the deformation, and the results were used for comparison with the proposed method.

\section{Results and discussion}

Figure 6 shows the deformation versus the time curves for the fourth specimen of concrete L1 obtained from the USB microscope and the traditional strain gauges. The loading and unloading cycles are very evident in the curves (Figure 6). This variation was captured by the DIC technique even though the reference length $(\Delta \mathrm{L}=13 \mathrm{~mm})$ of the image was different from the reference length of the traditional strain gauges $(\Delta \mathrm{L}=100 \mathrm{~mm})$. The difference between the two curves can be attributed to the non-homogeneity of the composite material as well the difference between the reference length adopted for each of the methods for calculating the deformation.

The DIC technique has always presented a greater deformation than the traditional strain gauges (Figure 6). For the highest stress levels, this difference is reduced. The difference percentage between the curves at point $A$ is $6,5 \%$ and at point $B$ is $47.8 \%$.

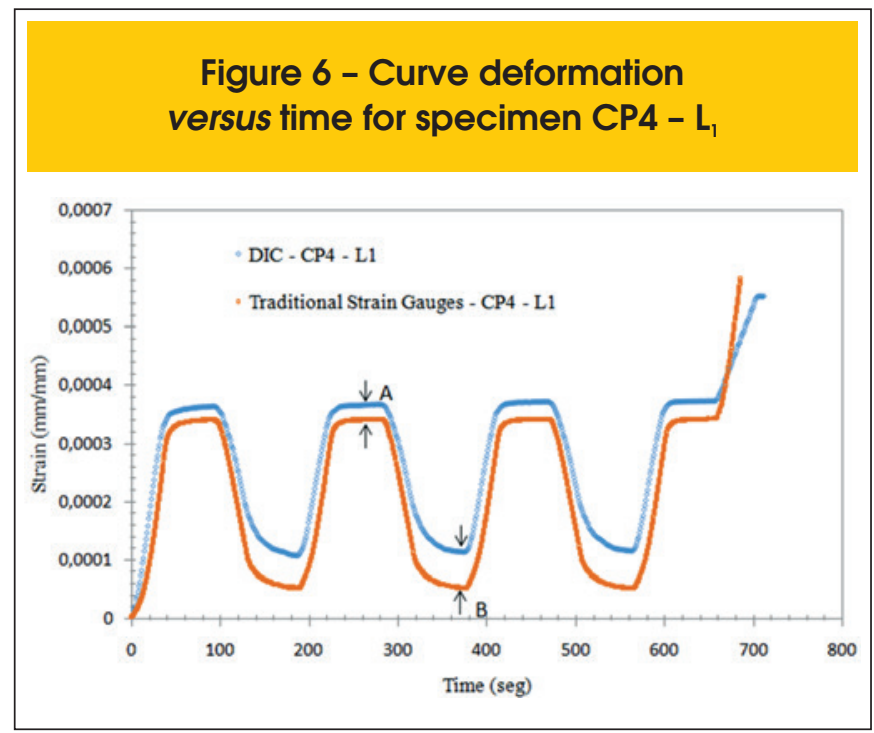

An improved fitting in the curves for the highest stress may demonstrate that the DIC technique enhances their sensitivity as the deformation increases.

Figure 7 shows typical stress-strain curves for the cylindrical concrete sample CP4 - $L_{1}$ that is obtained from the USB microscope and the traditional strain gauges. The resulting curves are very similar to each other. The horizontal shift in the axis of the deformation is a direct consequence of the difference observed and discussed in Figure. 5.

The dispersion of the data (Figure 7) that occurred in the loading and unloading cycles could be related to the fact that the test is held at the same stress level for 30 seconds to stabilize. The cycles may vary because of the apparatus oscillation in the load, which occurs to maintain the stress. For this sample, the difference between the values of the elasticity modulus for the DIC technique and the traditional strain gauges was approximately $3 \%$.

For the other samples, similar curves were obtained, and the average of the elasticity modulus and the standard deviation was calculated (Table 2).

For concrete $L_{1}$, the average elasticity modulus that was obtained using the DIC technique was $30.56 \mathrm{GPa}$, and the average elasticity modulus that was obtained using the traditional strain gauges was $29.49 \mathrm{GPa}$. For concrete $\mathrm{L}_{2}$, the average elasticity modulus obtained using the DIC technique was $28.75 \mathrm{GPa}$, and the average elasticity modulus that was obtained using the traditional strain gauges was $27.97 \mathrm{GPa}$. The values obtained for the two types of gauges are similar. The difference between these values for the $L_{1}$ concrete was $3.63 \%$, and the difference between these values for the $L_{2}$ concrete was $2.8 \%$. This divergence can be attributed to the differences of the analysis points, the difference between the reference lengths $(\Delta L)$ used to compute the strain for each method and the very characteristic of the inhomogeneous concrete.

For table 2, it is noticed that to DIC strain values using a microscope, thus with a small "optical" strain gauge size $(13 \mathrm{~mm}$, of same order of the mean size of the coarse aggregates), has very similar results with a large strain gauge size $(100 \mathrm{~mm})$. Analyzing the traditional strain gauge it is observed that it utilizes two diametrically opposed measures, so that the result is an average between these two val-

\section{Figure 7 - Stress-strain curve for a 28-day cylindrical concrete sample CP4 - $\mathrm{L}_{1}$}

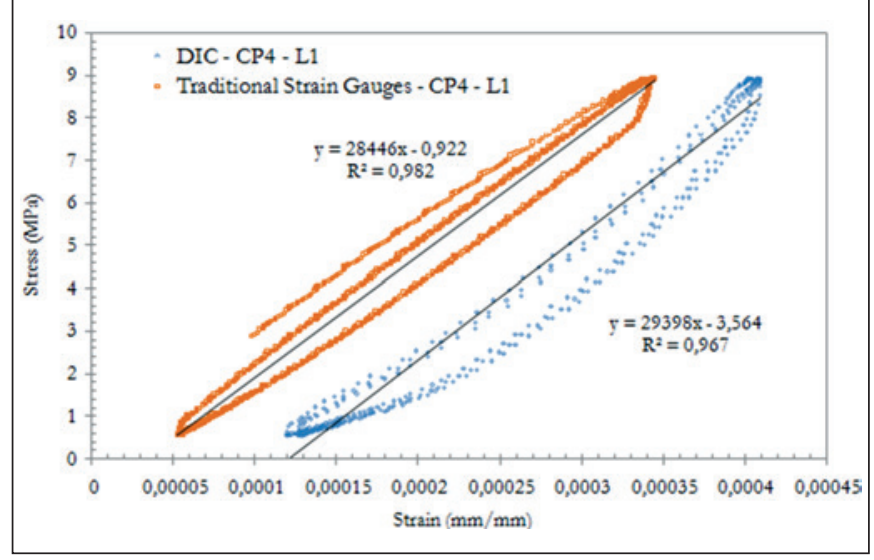




\section{Table 2 - Comparative data between the results obtained using the DIC technique and the traditional strain gauges (MPa)}

\begin{tabular}{|c|c|c|c|c|c|c|c|c|}
\hline \multirow{3}{*}{$\begin{array}{l}\text { Type strain } \\
\text { gauge }\end{array}$} & \multicolumn{8}{|c|}{ Concrete type } \\
\hline & \multicolumn{4}{|c|}{$L_{1}$} & \multicolumn{4}{|c|}{$\mathrm{L}_{2}$} \\
\hline & Specimens & $\begin{array}{l}\text { Elasticity } \\
\text { modulus }\end{array}$ & Average & $\begin{array}{l}\text { Standard } \\
\text { deviation }\end{array}$ & Specimens & Average & $\begin{array}{l}\text { Elasticity } \\
\text { modulus }\end{array}$ & $\begin{array}{l}\text { Standard } \\
\text { deviation }\end{array}$ \\
\hline \multirow{5}{*}{$\mathrm{DIC}$} & CPI & 31541 & 30557 & 1431 & $\mathrm{CP1}$ & 29221 & 28748 & 1460 \\
\hline & CP2 & 28317 & 30557 & 1431 & CP2 & 27580 & 28748 & 1460 \\
\hline & CP3 & 31811 & 30557 & 1431 & CP3 & 26800 & 28748 & 1460 \\
\hline & CP4 & 29398 & 30557 & 1431 & CP4 & 31015 & 28748 & 1460 \\
\hline & CP5 & 31719 & 30557 & 1431 & CP5 & 29127 & 28748 & 1460 \\
\hline \multirow{5}{*}{$\begin{array}{l}\text { Traditional } \\
\text { strain } \\
\text { gauges }\end{array}$} & CP1 & 30763 & 29487 & 1072 & CP1 & 30283 & 27971 & 1542 \\
\hline & CP2 & 29084 & 29487 & 1072 & CP2 & 28284 & 27971 & 1542 \\
\hline & CP3 & 28376 & 29487 & 1072 & CP3 & 25576 & 27971 & 1542 \\
\hline & CP4 & 28446 & 29487 & 1072 & CP4 & 28446 & 27971 & 1542 \\
\hline & CP5 & 30767 & 29487 & 1072 & CP5 & 27267 & 27971 & 1542 \\
\hline
\end{tabular}

ues, which minimizes the possible effect of bending that can occur in the test. In the case of DIC as the monitored area (the reference length $\Delta \mathrm{L}=13 \mathrm{~mm}$ ) is small, the effect of bending is practically nonexistent. In order to validate this hypothesis the test was performed using DIC repeatedly changing the position of the microscope. The values found for the same specimen were different, but within the range of the standard deviation shown in Table 2. This result shows that the response DIC, even though localized, representing the macroscopic behavior of the axial compression test.

The results showed that the DIC technique provides values equivalent to the values obtained using traditional strain gauges as well as significant advantages. The first major advantage is that the DIC technique can be used without surface preparation or for the preparation of only a small region. Currently, no dependence exists for the randomness of the medium for this technique. The second major advantage is that the dynamics and flexibility of the DIC technique can be applied for studies in which the electrical strain gauge or mechanical strain gauge are not possible, including samples of various sizes. The third advantage includes the accuracy of the system, which can be improved in accordance with the situation by changing both the focal length and the focus area to achieve greater precision. Finally, the proposed system offers low-cost, easy use and sustainability because the hardware can be reused indefinitely.

\section{Conclusions}

A method for obtaining the concrete strain and displacements using a USB microscope $(800 \mathrm{x})$ and for determining the concrete elasticity modulus of compression has been proposed and validated in this paper. The values obtained by the proposed system were of the same order of magnitude of the values generated using the traditional strain gauge. A difference of up to $4 \%$ was found for the values of the modulus of elasticity.

New tests will be performed to improve this analysis. For example, a system will be developed for coupling the load to the images without the need for human intervention. In addition, the installation of other microscopes simultaneously will enable the identification of strains in the longitudinal and transverse plane as well as the outside shooting plane.

Generally, the digital image correlation technique is a technology with a wide range of applications in structures engineering and can be used with any type of material, such as wood and steel.

\section{Acknowledgments}

The authors gratefully acknowledge the important support received from FAPEMIG (Fundação de Amparo à Pesquisa do Estado de Minas Gerais) and Pró-Reitoria de Pesquisa da Universidade Federal de Minas Gerais - UFMG.

\section{Bibliographical references}

[1] ASSOCIAÇÃO BRASILEIRA DE NORMAS TÉCNICAS ABNT. NBR 8522. Concreto - Determinação do Módulo Estático de Elasticidade à Compressão e Diagrama TensãoDeformação. ABNT, p. 1-9, 2008.

[2] C469-02, Standard Test Method for Static Modulus of Elasticity and Poisson's Ratio of Concrete in Compression. ASTM, p. 1-5, 2002.

[3] HUANG, H.; LIU, L.; SHAM, F. C.; CHAN, Y. S.; NG, S. P. Optical Strain Gauge vs. Traditional Strain Gauges for Concrete Elasticity Modulus Determination. Optik - International Journal for Light and Electron Optics, v. 121, p. 1635-1641, 2010.

[4] HUANG, M.; JIANG, L.; LIAW, P. K.; BROOKS, C. R.; SEELEY, R.; KLARSTROM, D. L. Using Acoustic Emission in Fatigue and Fracture Materials Research. JOM - The Minerals, Metals \& Materials Society, v. 50, n.11, p.1-12, 1998. 
[5] KORENSKA, M.; PADZERA,L.; MANYCHOVA, M. Effects of Material Structure of Concrete on Acoustic Emission Signal Parameters. European Working Group on Acoustic Emission (EWGAE), 2010.

[6] CHU, T. C.; RANSON, W. F.; SUTTON, M. A. Applications of digital-image-correlation techniques to experimental mechanics. Experimental Mechanics, v. 25, p. 232-244, 1985.

[7] SUTTON, M.A.; CHENG, M.; PETERS, W. H.; CHAO, Y. J.; MCNEILL, S. R. Application of an Optimized Digital Correlation Method to Planar Deformation Analysis. Image Vision Computer, v. 4, p. 143-150, 1986.

[8] BRUCK, H.; McNEILL, S.; SUTTON, M. A.; PETERS, W. Digital Image Correlation Using Newton-Raphson Method of Partial Differential Correction. Experimental Mechanics, v. 29, p. 261-267, 1989.

[9] LUO, P. F.; CHAO, Y. J.; SUTTON, M. A.; PETERS, W. H. Accurate Measurement of Three Dimensional Deformations in Deformable and Rigid Bodies Using Computer Vision. Experimental Mechanics, v. 33, p. 123-132, 1993.

[10] HUANG, Y.H.; QUAN, C.; TAY, C.J.; CHEN, L. J. Shape Measurement by The Use of Digital Image Correlation. Optical Engineering, v. 40 n.8, p. 1-7, 2005.

[11] SANTOS, A. H. A.; PITANGUEIRA, R. L. S.; RIBEIRO, G. O; CALDAS, R. B. Study of size effect using Digital Image Correlation. Revista Ibracon, v.8 n.3, p.323-340, 2015

[12] HUNG, Y. Y.; SHEAROGRAPHY: A New Optical Method for Strain Measurement and Nondestructive Testing. Optical Engeeniring, v. 21, n.3, p.391-395, 1982.

[13] HUANG, Y. H.; NG, S.P.; LIU, L.; CHEN, Y. S.; HUNG, M.Y. $Y$. Shearographicphase Retrieval Using One Single Specklegram: A Clustering Approach. Optical Engeenring, v. 47, n. $5,2008$.

[14] SUTTON, M. A.; McNEILL, S. R.; HELM, J. D.; CHAO, Y. J. Advances in Two-Dimensional and Three-Dimensional Computer Vision. Topics in Applied Physics, v. 77, p. 323-372, 2000.

[15] LAGATTU F, BRILLAUD J, LAFARIE-FRENOT MC. High strain gradient measurements by using digital image correlation technique. Mater Charact 2004;53:17-28.

[16] LOCKWOOD WD, TOMAZ B, REYNOLDS AP. Mechanical response of friction stir welded AA2024: experiment and modeling. Mater Sci Eng 2002;A323: 348-53.

[17] Reynolds AP, Duvall F. Digital image correlation for determination of weld and base metal constitutive behavior. Welding J 1999;78(10):355s-60s.

[18] YAN J, SUTTON MA, REYNOLDS AP, SAMER A, HORSLEY $D$. Characterization of heterogeneous response of pipeline steel weld using digital image correlation. In: Proceedings of the 2006 SEM annual conference and exposition on experimental and applied mechanics, June 4-7 2006, St Louis, Missouri, USA, 2006, vol. 1. p. 90-6.

[19] PETERS, W. H.; RANSON, W. F.; Digital Imaging Techniques in Experimental Stress Analysis. Optical Engineering, v. 21, p. $427-431,1981$.

[20] CHOI, S.; SHAH, S. P. Measurement of Deformations on Concrete Subjected to Compression Using Image Correlation. Experimental Mechanics, v. 37, p. 307-313, 1997.

[21] PAN, B.; QUIAN, K.; XIE, H.; ASUNDI, A. Two-dimensional Digital Image Correlation for in-plane Displacement and
Strain Measurement: A Review. Measurement Science and Technology, v. 20, p. 1-17, 2009.

[22] McCORMICK, N.; LORD, J. Digital Image Correlation for Structural Measurements. Civil Engineering, v. 165, p. 185190, 2012.

[23] SUTTON, M.A.; ORTEU, J.-J.; SCHREIER, H.W.. Image Correlation for Shape, Motion and Deformation Measurements - Basic Concepts, Theory and Applications, Springer, 2009. ISBN 978-0-387-78746-6.

[24] CORR, D.; ACCARDI, M.; GRAHAN-BRADY,L.; SHAH, S. P.; Digital Imaging Correlation Analysis of Interfacial Debonding Properties and Fracture Behavior in Concrete. Engineering Fracture Mechanics. v. 74, n.1-2, p. 109-121, 2007.

[25] HELM, J. D.; Digital Image Correlation for Specimens with Multiple Growing Cracks. Experimental Mechanics, v. 48, p. 753-762, 2008.

[26] SUBRAMANIAN, K.V.; ALI-AHMAD, M.; GHOSN, M. Freeze- Thaw Degradation of FRP-Concrete Interface: Impact on Cohesive Fracture Response. Engineering Fracture Mechanics, v. 75, n. 13, p. 3924-3940, 2008.

[27] WU, Z.; RONG, H.; ZHENG, J.; XU, F.; DONG, W. An Experimental Investigation on the fpz Properties in Concrete Using Digital Image Correlation Technique. Engineering Fracture Mechanics, v. 78, p. 2978-2990, 2011.

[28]L. ROBERT, F. NAZARET, J.-J. ORTEU, T. CUTARD. Use of 3-D Digital Image Correlation to characterize the mechanical behavior of a Fiber Reinforced Refractory Castable, Experimental Mechanical. v. 47(6), p.761-773, 2007.

[29] M.A. SUTTON, J.H. YAN, V. TIWARI, H.W. SCHREIER, J.J. ORTEU; "The effect of out of plane motion on $2 \mathrm{D}$ and $3 \mathrm{D}$ digital image correlation measurements" Optics and Lasers in Engineering, V.46(11), p.746-757, 2008

[30] GUETTI, P. C., Contribuição ao Estudo das Propriedades Mecânicas do Concreto Autoadensável e do Concreto Autoadensável Reforçado com Fibras de Aço, Phd Dissertation, University Federal of Minas Gerais - UFMG, 2012 <http://www.pos.dees.ufmg.br/defesas/420D.PDF> 